\title{
Sales force compensation and incentive schemes: practices in the South African pharmaceutical industry
}

\author{
Russell Abratt* \\ Graduate School of Business Administration, University of the Witwatersrand, Johannesburg. P.O. Box 98. WITS, 2050 South Africa \\ Abrattr(d)zeus.mgmt.wits.ac.za \\ Manfred Klein \\ Graduate School of Business, University of the Witwatersrand, Johannesburg, P.O. Box 98, WITS. 2050 South Africa
}

\begin{abstract}
Compensation plans that incorporate incentive schemes act as a sales force motivator. This study deals with sales force compensation plans from a management perspective, in the South African pharmaceutical industry. A literature review of incentive schemes is provided. Results are reported about the compensation plans and incentive schemes of 38 organisations. The design, implementation, and evaluation of sales force compensation and incentive schemes are discussed. Guidelines for the development of sales force incentive schemes are provided.
\end{abstract}

*Author to whom correspondence should be addressed.

\section{Introduction}

The cost of a sales force is rising and is by far the largest element in a company's marketing expenditure. A survey of the South African pharmaceutical industry in 1978 found that the sales force cost between $\mathbf{4 0}$ and $\mathbf{7 5 \%}$ of the company's marketing budget (Flint, 1991). Therefore companies need to ensure that their sales forces are highly productive and motivated. As a result, companies consequently try to improve the productivity of their sales force through better selection, training, motivation and compensation. Of these, compensation and incentive schemes play an important role in motivating sales people to perform better.

The purpose of this study was to investigate compensation plans and incentive schemes of pharmaceutical companies operating in South Africa. There are very few studies on sales management issues in the pharmaceutical industry worldwide. Richardson, Swan \& McInnis-Bower (1994) and Bush \& Grant (1994) analysed the content of four leading marketing and sales journals for a 17- and 13-year period respectively. Only $2.6 \%$ of the articles were on the topic of compensation and $9.7 \%$ of the articles dealt with the pharmaceutical industry (Richardson, Swan \& McInnis-Bower, 1994). In addition, the size of the industry warrants research of this nature.

The South African Pharmaceutical industry is dominated by foreign companies. According to the Pharmaceutical Manufacturers Association of South Africa, more than $30 \%$ of domestic demand for pharmaceuticals is imported. Imports grew in nominal figures from R501.8 million in 1990 to R1282.7 million in 1995, an increase of $155 \%$. The total pharmaceutical market in 1995 was R4594 million of which the prescription market accounted for $75.3 \%$ of the total (PMA, 1997).

In summary, the purpose of this study was to analyse incentive schemes in operation, and to draw up guidelines that will assist sales management with the future design of incentive plans.

\section{Context}

\section{Motivation and compensation}

Compensation deals with every type of reward individuals receive in exchange for performing organisational tasks. Employees can be paid for the time they work, their skills and knowledge, the output they produce, and competencies or a combination of these factors (Ivancevich, 1998). Variable pay has become a popular method of payment as it links reward to performance or productivity (Smith, 1992). Methods for paying eniployees on the basis of output are usually referred to as incentive forms of compensation. Pay motivates job performance to the extent that merit increases and other work-related rewards are allocated on the basis of performance (Milkovich \& Newman, 1990).

Motivation is the set of attributes and values that predisposes a person to act in a specific, goal-directed manner (Ivancevich, 1998). Motivation at work has been identified as occurring in two ways: intrinsic motivation is derived from job content, and can be described as the process of motivation by work itself in so far as it meets people's needs or leads to the expectation that their goals will be achieved (Flude, 1992). People seek the type of work that satisfies them, and intrinsic motivation is therefore self-generated. Extrinsic motivation refers to what is done for people to motivate them. It arises from the provision by management of rewards such as salary increases and promotion. Extrinsic motivators are said to have an immediate and powerful effect, but may not be long lasting (Armstrong \& Murlis, 1994). This review will be concerned primarily with extrinsic motivation of the sales force.

The specific nature of the sales job together with the personality of the sales person, the diversity of company goals, and the changing character of market conditions greatly influence the motivation level and therefore the performance of sales representatives (Ingram, Schwepker \& Hudson, 1992; Steinbrink, 1978).

Most sales people rate monetary rewards as the best motivator (Walker, Churchill \& Ford, 1977; Bagozzi, 1980; Berry \& Abrahamsen, 1981; Churchill \& Pecotich, 1982; Churchill, 
Ford \& Walker, 1993). In a South African survey, most sales executives use incentive payments predominantly to motivate their sales representatives (Abratt \& Smythe, 1989). A sales person's job satisfaction is seen by both sales representatives and sales management as a key motivator (Winer \& Schiff, 1980; Jackson \& Hisrich, 1996; Doyle \& Shapiro, 1980; Churchill, Ford \& Walker, 1997).

The design, implementation, evaluation and regular adjustments of incentive plans is an important task for management. In a survey of more than $\mathbf{4 0 0}$ industrial firms in the United States, more than one third of them were unhappy with their incentive programs (Churchill, Ford \& Walker, 1993). Sales management has to decide on three basic compensation plans for its sales force, a salary-only plan, a commission-only plan, or a combination plan (Steinbrink, 1978; Jackson \& Hisrich, 1996; Churchill, Ford \& Walker, 1997). The literature states that there are advantages to all types of plans as well as disadvantages (Steinbrink, 1978; Jackson \& Hisrich, 1996; Churchill, Ford \& Walker, 1997; Stanton, Buskirk \& Spiro, 1995). The straight salary plan is useful for missionary selling tasks or when the allocation of sales results to a single sales representative is not easy. The straight commission plan is useful for companies that are only interested in improving sales volume or profitability.

The most widely used plan is a combination of base salary and financial incentives, such as commission, bonus or sales contests (Churchill, Ford \& Walker, 1997; Barnes, 1986). A combination plan is useful for companies that are interested in both selling activities and non-selling duties, such as customer service and new account management.

Sales quotas can be defined as specific goals set for sales people who are made responsible for attaining them over a specific period of time. The ime p-riod is usually one year (Good \& Stone, 1991).

Quotas are used as the basis for paying out incentives (Churchill, Ford \& Walker 1997; Barnes, 1986; Dubinsky \& Barry, 1982). The most important kind of quota is sales volume. Only a minority of firms use qualitative measures, such as morale and loyalty (Dubinsky \& Barry, 1982; Churchill, Ford \& Walker, 1997). In most companies, incentive payment is only due when a sales per on reaches $100 \%$ of their quota (Barnes, 1986).

Many companies use incentive caps or ceilings on potential compensation. This policy limits costs, but can also have a negative impact on the motivation of sales people with outstanding performance. Sales people who achieve much more than $100 \%$ of quota would therefore be prevented from receiving deserved rewards (Barnes, 1986). Many researchers believe that sales incentive schemes loose their effectiveness over time and should therefore be updated regularly. This is mainly due to changing market conditions (Churchill \& Pecotich, 1982). Incentive plans should be reviewed at least once a year or when required (Barnes, 1986; Jackson \& Hisrich, 1996; Lidstone, 1978).

Many different compensation packages are in use for sales forces in different industries. The results of previous studies can be summarised as follows. Most companies use a combination incentive plan. Only a few use a salary-only or a commission-only scheme (Barnes, 1986; Churchill, Ford \& Walker, 1997; Steinbrink, 1978). The most widely used com- bination plan is salary plus commission. Over the last 30 years the incentive proportion of the sales compensation plan has increased (Barnes, 1986: Churchill, Ford \& Walker, 1997; Stanton, Buskirk \& Spiro, 1995). The majority of sales representatives prefer a combination plan consisting of a base salary plus a form of incentive (Ingram. Schwepker \& Hutson, 1992; Winer \& Schiff, 1980).

Non-financial rewards consist mainly of promotion oppor. tunities, recognition programs and programs to improve selfesteem. They are long-term additional motivators for sales representatives (Bagozzi, 1980: Churchill. Ford \& Walker, 1997; Futrell, Parasuraman \& Sagar. 1983). Non-financial rewards are mainly seen as less important than financial incentives. Specifically designed programs to enhance a sales representative's motivation via non-financial rewards are not used very often (Steinbrink, 1978; Winer $\&$ Schiff, 1980). For Bagozzi, non-financial rewards are at least as important as monetary incentives (Bagozzi, 1980). A balanced combination of both methods can enhance motivation and therefore the performance of sales people.

\section{Research propositions}

The literature review leads to the formulation of five propositions for this study.

$\mathrm{Pl}$ :Sales force incentive schemes are part of the compensation package of most pharmaceutical companies (Barnes, 1986; Churchill, Ford \& Walker, 1993; Steinbrink, 1978; Winer \& Schiff, 1980).

P2: A combination of base salary, commission and sales contests is the most frenuently practiced type of a sales force compensation package within the pharmaceutical industry (Barnes, 1986; Churchill, Ford \& Walker, 1993; Ingram, Schwepker \& Hudson, 1992; Steinbrink, 1978).

P3: The main reason for companies to use incentive schemes is to motivate their sales force (Bagozzi, 1980; Berry \& Abrahamsen, 1981; Churchill \& Pecotich, 1982; Churchill, Ford \& Walker, 1993; Doyle \& Shapiro, 1980; Jackson \& Hisrich, 1996; Ingram, Schwepker \& Hudson, 1992).

P4:Only a minority of pharmaceutical companies use nonfinancial rewards as additional motivators for sales people (Bagozzi, 1980; Churchill, Ford \& Walker, 1993; Futrell, Parasuraman \& Sagar, 1983; Steinbrink 1978; Winer \& Schiff, 1980).

P5:Most companies have fixed intervals for updating incentive schemes of one year or longer (Barnes, 1986: Churchill \& Pecotich, 1982; Churchill, Ford \& Walker, 1993; Jackson \& Hisrich, 1996; Lidstone, 1978).

\section{Methodology}

The research procedure was to take the following steps. A literature review was undertaken to understand the theory and to summarise prior research. The questionnaire was designed from previous studies and tıen tested in a pilot study. The pilot study was conducted on four managers from different pharmaceutical companies. They were asked for feedback on the content of the questionnaire and how long it took to complete as well as the numerical values of the questions. As a result, some minor changes were made. The sample was determined as the entire population of South African pharmaceutical companies. The questionnaire, together with 
a fax cover sheet and a personal covering letter were then faxed to the sample. Follow-up calls were undertaken ten to 14 days later. The completed questionnaires were then processed using appropriate analytical procedures.

\section{Questionnaire design}

The questionnaire in the Abratt \& Smythe (1989) survey was used as a basis for this study, but it was modified slightly to reflect the specific issues of the pharmaceutical industry as well as current issues. The questionnaire was divided into four sections.

The first asked for specific company data, the second the design of incentive schemes, the third was the management of incentive schemes, and the fourth was a set of open-ended questions.

The questionnaire was piloted on respondents from four different pharmaceutical companies.

The respondents were asked for feedback regarding the content of the questionnaire, the time it took to complete, and specifically the ranges of numerical values of several questions. As a result of this exercise several minor changes were made to the questionnaire. The questionnaire appeared easy to complete and took on average between 15 and 20 minutes.

\section{Sample}

The population for this study consisted of sales and marketing managers or human resources managers of all pharmaceutical companies in South Africa who are responsible for the development of sales force compensation schemes. The lists of members of the National Association of Pharmaceutical Manufacturers as well as the Pharmaceutical Manufacturers' Association were used. These reflected a total of 185 different companies. Most of these belonged to larger parent companies. Therefore, only companies with individual sales policies were included in the universe. These consisted of 62 separate pharmaceutical companies.

\section{Data analysis}

The questionnaire consisted of fixed alternative questions and open-ended questions. The questions were edited and coded before the responses were coded. A well-known computer software package was used to tabulate the responses. Frequency distributions, percentages, measures of central tendency and dispersion were derived from simple tabulations. The data were entered twice to ensure accuracy. The openended questions were analysed by content analysis. The answers were categorised and the responses counted. This led to a set of nominal data which were then analysed.

\section{Results}

\section{Profile of respondents}

Of the 62 companies in the sample 39 companies responded. One questionnaire had to be discarded because of a lack of completeness and consistency. Thus a total of 38 usable replies were received resulting in a response rate of $61.3 \%$. A profile of the respondents is shown in Table 1.

The majority of companies were subsidiaries of foreign companies, mostly from the United States and Germany. Only $21.1 \%$ of respondents were South African owned. The prescription medicine sector is the most important market for
Table 1 Profile of respondents

\begin{tabular}{|c|c|c|}
\hline Country & Frequency & Percentage \\
\hline South Africa & 8 & 21.1 \\
\hline United States of America & 14 & 36.8 \\
\hline Germany & 8 & 21.1 \\
\hline Switzerland & 2 & 5.3 \\
\hline United Kingdom & 1 & 2.6 \\
\hline Others & 5 & 13.1 \\
\hline Total & 38 & 100 \\
\hline \multicolumn{3}{|c|}{ Industry sector } \\
\hline Prescription: Products of original research & 21 & 55.3 \\
\hline Prescription: Generic products & 9 & 23.7 \\
\hline Over-the-counter (OTC) products & 7 & 18.4 \\
\hline Other & 1 & 2.6 \\
\hline Total & 38 & 100 \\
\hline \multicolumn{3}{|c|}{ Annual sales volume (Rmil.) } \\
\hline 5 to 19 & 4 & 10.5 \\
\hline 20 to 49 & 9 & 23.7 \\
\hline 50 to 99 & 5 & 13.2 \\
\hline 100 and above & 20 & 52.6 \\
\hline Total & 38 & 100 \\
\hline \multicolumn{3}{|c|}{ Size of the sales force } \\
\hline 1 to 5 & 1 & 2.6 \\
\hline 6 to 10 & 4 & 10.5 \\
\hline 11 to 20 & 13 & 34.2 \\
\hline 21 to 50 & 13 & 34.2 \\
\hline 51 and above & 7 & 18.5 \\
\hline Total & 38 & 100 \\
\hline
\end{tabular}

the majority of companies. More than half of all companies were large with annual sales volumes of R100 million or more, and employed sales forces of more than 21 sales representatives.

\section{Compensation plans}

The pharmaceutical companies used many different compensation plans. These are shown in Table 2.

All companies used a combination plan with a base salary plus one or more incentives. The most important single plan was salary plus group bonus plus commission plus sales contest, followed by salary plus commission.

In addition to salary and incentives, the sales representatives receive other benefits. These are additional payments to satisfy sales people's security needs. These are shown in Table 3 .

All firms offered their sales representatives a company car or a car scheme. Most companies offered medical aid, a cellular phone, a pension scheme, an expense allowance and disability insurance. Most companies saw benefits as additional standard industry payments to their employees and thus not as an incentive itself.

The driving factors for the use of incentive schemes by the respondents are shown in Table 4.

The most important reasons companies used sales incentives were to motivate the sales force, and to direct the efforts 
Table 2 Sales force compensation packages in use

\begin{tabular}{lcc}
\hline Type & Frequency & Percentage \\
\hline Salary + Group Bonus + Commission + Sales Contest & 9 & 23.7 \\
Salary + Commission & 8 & 21.1 \\
Salary + Individual Bonus + Sales Contest & 5 & 13.2 \\
Salary + Commission + Sales Contest & 5 & 13.2 \\
Salary + Individual Bonus & 3 & 7.9 \\
Salary + Individual Bonus + Group Bonus + Sales Contest & 2 & 5.3 \\
Salary + Group Bonus & 1 & 2.6 \\
Salary + Sales Contest & 1 & 2.6 \\
Salary + Individual Bonus + Commission & 1 & 2.6 \\
Salary only & - & - \\
Commission only & - & - \\
Other & 3 & 7.8 \\
\hline Total & 38 & 100 \\
\hline
\end{tabular}

Table 3 Benefits received by the sales force

\begin{tabular}{lcc}
\hline Benefit & Frequency & Percentage \\
\hline Company car/car scheme & 38 & 100 \\
Medical aid & 35 & 92.1 \\
Cell phone/allowance & 35 & 92.1 \\
Pension scheme & 34 & 89.5 \\
Expense allowance & 32 & 84.2 \\
Life insurance & 27 & 71.1 \\
Disability insurance & 25 & 65.8 \\
Employee stock purchase & 5 & 13.2 \\
plan & & \\
Profit sharing & 3 & 7.9 \\
Others & 1 & 2.6 \\
\hline
\end{tabular}

of the sales force. The least important factor was to make the sales force work harder. Thus, organisations use incentives to influence behaviour positively, not only to increase performance, but also to reward them appropriately.

Because motivation of the sales force was found by Abratt \& Smythe (1989) as the most important reason why companies use incentive schemes, respondents were asked to rank motivating factors in order of importance. These are shown in Table 5.

Self-satisfaction in doing a good job was rated as the most important factor with satisfying customer needs as the second most important. The two least important factors were to keep one's job and to improve one's lifestyle. These results are in line with the findings of Winer \& Schiff (1980). One must note that these findings reflect the opinion of managers, not that of salespeople.

Companies were asked to indicate how the increase in base salary for their sales representative were determined. Altogether $79 \%$ based salary increase on a performance appraisal. The fair market rate was used by $50 \%$ of the respondents and $24 \%$ took cost of living rises into account.

The time a sales person has worked for a company was not seen as a criterion to determine salary increases at all.

\section{Incentive schemes}

As far as the allocated responsibility for the design of incentive schemes are concerned, the three people mainly involved were the sales manager $(92.1 \%)$, the general

Table 4 Driving factors for use in incentive schemes

\begin{tabular}{lcc}
\hline Factor & Frequency & Percentage \\
\hline To motivate the sales force & 28 & 73.9 \\
To direct the efforts of the sales force & 25 & 65.8 \\
To increase sales per sales person & 13 & 34.2 \\
To assist in managing the sales force & 6 & 15.8 \\
To relate sales costs to sales performance & 5 & 13.2 \\
To make the sales force work harder & 3 & 7.9 \\
\hline
\end{tabular}

manager $(73.7 \%)$ and the marketing manager. The human resources department was generally not involved in the design of incentive schemes. The sales staff were also consulted by very few firms (5.2\%). This is surprising because Stanton et al. (1995) suggests that management should solicit suggestions from the sales force regarding a compensation plan. Sales people are more likely to accept a plan if they were consulted about it during its design and development.

Respondents were asked to indicate what measures they used to establish incentive payments. This is shown in Table 6.

The three most important measures were 'sales above a target', 'company performance', and 'different rates by product category'. Very few companies used 'market information' as a basis for incentive payments. The results show that managers believe that the major driving force for use in incentive schemes is to motivate the sales force (Table 4). Only $34.2 \%$ of the managers noted that incentives were designed to increase sales per sales person. However, the most important measure used for incentive payments, was 'sales above target' (Table 6). This points at an anomaly in the sense that management has a hidden agenda when they purportedly want to 'motivate' sales people.

Table 5 Factors motivating the sales force

\begin{tabular}{lccc}
\hline Factor & \multicolumn{3}{c}{ Percentage of respondents } \\
\hline & $\begin{array}{c}\text { Most } \\
\text { important } \\
\text { factor }\end{array}$ & $\begin{array}{c}\text { Second most } \\
\text { important } \\
\text { factor }\end{array}$ & $\begin{array}{c}\text { Least } \\
\text { important } \\
\text { factor }\end{array}$ \\
\hline Self-satisfaction in doing a good job & 31.6 & 26.3 & - \\
Satisfy customer needs & 26.3 & 10.5 & 2.6 \\
Make more money & 15.8 & 23.7 & 2.6 \\
Receive recognition & 13.2 & 13.2 & - \\
Increase chance of promotion & 7.9 & 5.2 & 26.3 \\
Improve lifestyle & 2.6 & 21.1 & - \\
Keep job & 2.6 & - & 68.5 \\
\hline Total & 100 & 100 & 100 \\
\hline
\end{tabular}


Table 6 Measures used for incentive payments

\begin{tabular}{lcc}
\hline Basis for Payment & Frequency & Percentage \\
\hline Sales above a target & 28 & 73.7 \\
Company performance & 25 & 65.8 \\
Different rates by product. category & 15 & 39.5 \\
Market information & 4 & 10.5 \\
Product gross margin & 1 & 2.6 \\
A fixed commission on all sales & - & - \\
Morale & - & - \\
\hline
\end{tabular}

Companies that pay their sales representatives for customer, competitor and other information may have an advantage in the market place. Morale was not seen as an important factor, perhaps due to the problem of quantifying it. Stanton et al. (1995) states that high morale is of great importance for sales forces to achieve excellent results.

The gross earnings of sales representatives as well as the split between salary and incentives is shown in Table 7 .

There was a broad range in the annual average gross earnings of sales representatives. The two most popular salary maximums were R100 000 and R120000. The large differences in compensation payments were possibly due to a lack of industry information. Companies seem to have no knowledge of competitors' compensation plans. All respondents made use of a combination plan with a fixed salary portion and an incentive portion. The most popular split was $80 \%$ salary, $20 \%$ incentive, followed by $90 / 10$ and $70 / 30$. These findings clearly show that the majority of pharmaceutical firms do not use a high incentive proportion of total payment.

Table 7 Average annual gross salary and split between salary and incentives

\begin{tabular}{lcc}
\hline $\begin{array}{l}\text { Average gross earning p.a. } \\
\text { in R }\end{array}$ & Frequency & Percentage \\
\hline$-61000-70000$ & 1 & 2.6 \\
$-71000-80000$ & 1 & 2.6 \\
$-81000-90000$ & 5 & 13.2 \\
$-91000-100000$ & 9 & 23.7 \\
$-101000-110000$ & 1 & 2.6 \\
$-111000-120000$ & 9 & 23.7 \\
$-121000-130000$ & 2 & 5.3 \\
$-131000-140000$ & 4 & 10.5 \\
-141000 & 3 & 7.9 \\
- Not applicable & 3 & 7.9 \\
\hline Total & 38 & 100 \\
\hline Split in \% (Salary/Incentives) & & \\
-90/10 & 8 & 21.1 \\
-80/20 & 16 & 42.1 \\
- 70/30 & 6 & 15.8 \\
-60/40 & 2 & 5.3 \\
- 50/50 & 1 & 2.6 \\
- Other & 1 & 2.6 \\
- Not applicable & 4 & 10.5 \\
\hline Total & 38 & 100 \\
\hline & & \\
\hline & & \\
\hline
\end{tabular}

This may be due to the specific working conditions of pharmaceutical sales representatives. They sell products which demand a higher level of knowledge and more time to educate and inform customers. Thus non-selling activities are more important than in some other industries.

Most of the respondents used ceilings on incentive payments. Sixty-one percent of the companies stated that their incentive ceiling was $40 \%$ of base salary.

Altogether $17 \%$ used a ceiling of $60 \%$ and $4 \%$ used a ceiling of a $100 \%$; $18 \%$ had a ceiling of over a $100 \%$.

Bonuses are an important aspect of sales incentive plans. Seventy-three percent of respondents used bonuses as an incentive. Bonuses were paid out quarterly by $57 \%$ of firms, annually by $29 \%$ and monthly by $14 \%$. To be effective motivators, bonus payments should be paid out shortly after a sales representative reaches the necessary performance or quota. The ideal payment frequency of bonuses would therefore be a payment every month.

Many researchers stress the importance of non-financial rewards as additional motivators for salespeople (Churchill, Ford \& Walker, 1997; Futrell, Parasuraman \& Sagar, 1983; Bagozzi, 1980; Steinbrink, 1978).

Only $34 \%$ of respondents actually used this kind of incentive. The most important type of non-monetary incentive was recognition programmes. Companies using them could therefore attain a competitive advantage in the market place through higher motivated and better performing sales representatives. Incentives schemes need to be reviewed and updated as market conditions change. Most firms in the sample (71.1\%) reviewed compensation plans on an annual basis, $13.2 \%$ reviewed them as required and $7.9 \%$ reviewed them quarterly. The rest reviewed their compensation plans semiannually.

\section{Management of incentive schemes}

The respondents were asked to give their opinion on issues of management and implementation of incentive schemes.

More than $60 \%$ of all companies emphasised that sales management have flexibility with regard to the issue of incentive awards. Flexibility is important to meet unforeseeable situations which are out of the control of the sales representative.

These situations like production problems or supply problems can affect the individual performance of sales people negatively and can make quota attainment impossible. Eighty-three percent of the respondents stated that targets must be strictly achieved for incentives to be earned, and $97 \%$

Table 8 Potential negative side effects of incentive schemes

\begin{tabular}{lcc}
\hline Negative side effect & Frequency & Percentage \\
\hline Neglect of other products & 15 & 39.5 \\
Some staff not participating & 14 & 36.8 \\
Overstocking of customers & 13 & 34.2 \\
Neglect of non-selling duties & 9 & 23.7 \\
Cheating or deliberate disregard for company policy & 8 & 21.1 \\
Others & 1 & 2.6 \\
No answer & 5 & 13.2 \\
\hline
\end{tabular}


mentioned top management support for sales incentive schemes.

Management also recognised the potential negative side effects of incentive schemes. This is shown in Table 8.

The three most often mentioned negative side effects were 'neglect of other products', 'some staff not participating' and the 'overstocking of customers'. The reason for some staff not participating is that they don't buy into the system as they perceive it as unfair or not well designed. Most of these can be prevented by designing incentive plans with secondary and tertiary goals, such as special incentives for non-selling duties like administrative work, or additional incentives for less important product lines.

\section{Monitoring of the sales force and evaluation of com- pensation plans}

Monitoring or supervision of sales representatives is an essential management task and is aimed to provide training and assistance, enforcement, better performance and improved morale. According to Stanton et al. (1995) several techniques can be called 'automatic supervisory techniques'. These include the compensation plan.

This is by far the most important automatic supervisory tool because it encourages representatives to do those things that will maximise their earnings. Table 9 shows the methods management use to monitor their sales forces.

The most common methods employed to monitor or to supervise the sales force were 'meeting sales objectives, turnover against set targets, call rate, and market share'.

Table 9 Methods employed to monitor the sales force

\begin{tabular}{lcc}
\hline Method & Frequency & Percentage \\
\hline Meeting sales objectives & 32 & 84.2 \\
Turnover against set targets & 29 & 76.3 \\
Call rate & 25 & 65.8 \\
Market share & 22 & 57.9 \\
Turnover against territory potential & 13 & 34.2 \\
Customer relations & 11 & 28.9 \\
Internal relations & 8 & 21.1 \\
Number of orders & 5 & 13.2 \\
Gross profit per order & 4 & 10.5 \\
New accounts & 3 & 7.9 \\
\hline
\end{tabular}

Table 10 Criteria used to evaluate the effectiveness of incentive schemes

\begin{tabular}{|c|c|c|}
\hline Criterion & Frequency & Percentage \\
\hline Measurement against budget & 32 & 84.2 \\
\hline $\begin{array}{l}\text { Sales per product before vs. after the introduction } \\
\text { of sales incentives }\end{array}$ & 18 & 47.4 \\
\hline $\begin{array}{l}\text { Total sales before vs. after the introduction of sales } \\
\text { incentives }\end{array}$ & 18 & 47.4 \\
\hline $\begin{array}{l}\text { Market share before vs. after the introduction of } \\
\text { sales incentives }\end{array}$ & 15 & 39.5 \\
\hline Staff turn-over & 4 & 10.5 \\
\hline $\begin{array}{l}\text { Total sales costs before vs. after the introduction of } \\
\text { sales incentives }\end{array}$ & 4 & 10.5 \\
\hline
\end{tabular}

Qualitative methods, such as 'customer relations' and 'internal relations' were not used often.

The criteria used to evaluate the effectiveness of incentive schemes is shown in Table 10.

The main criterion used by $84.2 \%$ of all respondents was 'measurement against budget'. Other criteria used by $47.45 \%$ of the sample were sales per product before versus after the introduction of sales incentives, and total sales before versus after the introduction of sales incentives.

\section{Research propositions and results}

The findings will be tied to the set propositions.

P1:Sales force incentive schemes are part of the compensation package of most pharmaceutical companies.

Incentives were found to be part of the compensation package of all pharmaceutical firms. All companies used a combination plan with a base salary and one or more incentives. Thus proposition one is supported.

P2: A combination of base salary, commission and sales contests is the most frequently practised type of a sales force compensation package within the pharmaceutical industry.

The single most important type of incentive plan was 'salary, plus group bonuses plus commission plus sales contest'. Only $13.2 \%$ of respondents used a combination of base salary, commission and sales contests. Thus proposition two has little support.

P3: The main reason for companies to use incentive schemes is to motivate their sales force.

The reason mentioned most often as to why pharmaceutical firms used incentive schemes was indeed to motivate their sales people. Proposition three is therefore supported.

P4:Only a minority of pharmaceutical companies use non-financial rewards as additional motivators for sales people.

The findings showed that $34.2 \%$ of respondents used nonfinancial rewards. Proposition four is thus supported.

P5:Most companies have fixed intervals for updating incentive schemes of one year or longer.

Most companies (71.1\%) updated their incentive plans on an annual basis. Thus proposition five can be supported.

\section{Discussion and implications}

There is clearly no single sales incentive plan that is suitable for all pharmaceutical firms. However, many. important generic principles of a sound compensation plan have been found. A well-designed scheme is able to improve the sales force's performance and productivity. Support from top management and other management functions is crucial for the success of incentive plans.

Sales staff should participate in the design phase of incentive plans. The plan should be designed according to industry standards and company requirements.

A successful sales incentive scheme needs to be planned properly. The following steps in designing a plan should be adhered to:

1. Assess the firm's marketing and sales objectives, account management policies, and current performance of the sales force. 
2. Identify aspects of job performance to be rewarded. For example, increase in sales, new customers, and improvement of non-selling duties.

3. Assess personal characteristics of sales people and their valences for alternative rewards.

4. Decide on the most appropriate level of total compensation.

5. Ascertain the most attractive and motivating mix of rewards.

6. Decide on the form of financial incentives.

7. Decide on the appropriate types of non-financial incentives.

8. Decide on the split between the fixed proportion (salary) and incentive portion of compensation.

9. Set targets and decide on the time frame of payments.

10. Communicate the program to the sales force.

11. Implement the plan, provide training, feedback, guidance and recognition.

Incentives must be directly linked to performance, that is, a correlation of efforts, results, and rewards.

Qualitative performance measures such as morale, product knowledge, customer satisfaction, and reporting style should be quantifiable, for example via a 10-point scale ranging from very poor to excellent. The total incentive payments should be linked to total sales, that is a specific percentage. This will ensure that there is an economic relationship between sales costs and sales volume. The base salary increases should be primarily based on performance appraisals. However, the experience and education of sales representatives should also be of importance. There should be no limits on incentive payments.

Extraordinary achievements should be rewarded with extraordinary payments. The best performers of the sales force would then be further motivated to reach even more stretching goals and can thereby be prevented from leaving the company.

Incentive schemes should be simple and uncomplicated to ensure that sales people do not have difficulties in understanding them, see the relationship between efforts and rewards, and are able to calculate what their incomes will be. Incentive schemes should be designed to be perceived as fair and equitable. Sales management should only base rewards on measurable performance and use non-measurable behaviour for the annual review of base salary. The compensation plans should be flexible to meet the needs of individual territories, products, customers and sales representatives. Nonfinancial rewards should be used as additional low cost incentives. Specifically designed programs to enhance recognition and self-esteem of sales representatives should be established. Incentive schemes must be clearly documented by a written statement to make it clear for every sales person beforehand what he or she will have to do to earn a specific reward.

\section{Conclusion}

This study shows that South African pharmaceutical firms have realised the importance of sales compensation plans for the success of their sales forces. All companies used incentives as motivators for their sales representatives.

The broad variety of different incentive plans in use and the lack of information about competitor compensation schemes seems to be due to the lack of a structured 'scientific' design and the implementation of such plans. An attempt has been made to remedy this situation by recommending an approach for management to use when designing sales compensation plans.

\section{References}

Abratt, R. \& Smythe, M.R. 1989. A survey of sales incentive programs. Industrial Marketing Management. 18: 209-214.

Armstrong, A. \& Murlis, H. 1994. Reward management: a handbook of remuneration strategy and practise. London: Kogan Page Limited.

Bagozzi, R.P. 1980. Performance and satisfaction in an industrial sales force: an examination of their antecedents and simultaneity. Journal of Marketing. 44: 65-77.

Barnes, L. 1986. Finding the best sales compensation plan, Sales and Marketing Management. 173: 46-50.

Berry, D. \& Abrahamsen, K. 1981. Three types of salesmen to understand and motivate, Industrial Marketing Management, 10: 207-218.

Bush, A.J. \& Grant, E.S. 1994. Analysing the content of marketing journals to assess trends in sales force research: 1980-1992, Journal of Personal Selling and Sales Management. XIV: 57-68.

Churchill, G.A.. Ford. N.M. \& Walker. O.C. 1993. Sales force management. Chicago: lrwin.

Churchill, G.A., Ford, N.M. \& Walker. O.C. 1997. Sales force management. Chicago: Inwin.

Churchill, G.A. \& Pecotich, A. 1982. A structural equation investigation of the pay satisfaction - valence relationship among sales people. Journal of Marketing, 46: 114-124.

Doyle, S.X. \& Shapiro. B.P. 1980. What counts most in motivating your sales force?, Harvard Business Review. 58: 133-140.

Dubinsky, A.J. \& Barry. T.E. 1982. A survey of sales management practices, Industrial Marketing Management, 11: 133-141.

Flint, G.R. 1991. Information technology as a competitive weapon in the marketing of ethical drugs. Unpublished M.B.A. Research Report.

Flude, R. 1992. The motivation and retention of managers in the $1990^{\circ} \mathrm{s}$, Recruitment Selection and Retention. 1: 4-10.

Futrell, C., Parasuraman. A. \& Sager. J. 1983. Sales force evaluation with evaluation with expectancy theory. Industrial Marketing. 12: 125-129.

Good, D.J. \& Stone, R.W. 1991. How sales quotas are developed. Industrial Marketing Management. 20: 51-55.

Ingram, T.N. Schwepker. C.H. \& Hutson. D. 1992. Why sales people fail, Industrial Marketing Management. 21: 225-230.

Ivancevich, J.M. 1998. Human resource management. Boston: McGraw Hill.

Jackson, R.W. \& Hisrich. R.D. 1996. Sales and sales management. New Jersey: Prentice Hall.

Lidstone, J. 1978. Motivating your sales force. Farnborough. England: Gower Press.

Milkovich, G.T. \& Newman, I.M. 1990. Compensation. Boston: Irwin.

PMA. 1997. Draft annual report (unpublished). May 1996-April 1997. Pretoria: Pharmaceutical Manufacturers Association of South Africa.

Richardson. L.D., Sean. J.E. \& Mclnnis-Bowers C. 1994. Sampling and data collection methods in sales force research: issues and recommendations for improvement. Journal of Personal Selling and Sales Management, XIV: $33-39$.

Smith, B. 1992 U.S. Compensation needs some radical changes. HR focus, 69: 13

Stanton, W.J., Buskirk. R.H. \& Spiro. R.L. 1995. Management of a sales force. Chicago: Irwin

Steinbrink, J.P. 1978. How to pay your sales force. Harvard Business Review, 56: 11-122.

Walker, O.C., Churchill, G.A. \& Ford. N.M. 1977. Motivation and performance in industrial selling: present knowledge and needed research, Journal of Marketing Research. XIV: 156-168.

Winer, L.\& Schiff. J.S. 1980. Industrial sales people's views on motivation, Marketing Management. 9: 319-323. 